\title{
Associações de trabalhadores no bairro paulistano da Mooca entre 1900 e 1920*
}

\section{Bruno Caccavelli **}

Resumo: O objetivo deste texto é traçar um panorama das associações de trabaIhadores do bairro paulistano da Mooca entre os anos 1900 e 1920, abordando o surgimento e coexistência das sociedades, seus tipos, endereços escolhidos para fixar as suas sedes e o funcionamento interno, a partir do cruzamento de informações obtidas em diversas fontes. Buscamos analisar também a dinâmica associativa e entender as formas com que identidades múltiplas, como a étnica e a de classe, se relacionavam.

Palavras-chave: associações; trabalhadores; bairro da Mooca - São Paulo (cidade).

Abstract: The purpose of this paper is to draw an overview of the workers' associations in Sao Paulo's district of Mooca between the years 1900 and 1920. By crossing information obtained from several sources, this text approaches the emergence and coexistence of societies, their types, addresses chosen to establish their head offices, and the internal workings. It also seeks to analyze the associative dynamics, and understand the ways in which multiple identities, such as ethnic and class were connected.

Keywords: associations; workers; district of Mooca - Sao Paulo (city).

\section{Reconhecendo o bairro da Mooca}

O bairro da Mooca, situado a leste do centro da cidade de São Paulo, foi palco de diversas mobilizações no início do século XX e a sua constituição esteve inserida entre a daqueles bairros que surgiam na cidade por grande afluxo e concentração de imigrantes e grande concentração de fábricas, onde a proximidade entre estes estabelecimentos fabris e as residências compunha um grande aglomerado de trabalho'. Contudo, se quando falamos de um "bairro operário" temos a

* Este texto é, com algumas alterações, parte do primeiro capítulo da dissertação desenvolvida com apoio financeiro da Fapesp.

** Mestre em História pela Universidade Federal de São Paulo.

1 GUZZO, Maria Auxiliadora Dias. A Vida Fora das Fábricas: cotidiano operário em São Paulo - 1927-1934. Rio 
impressão de que seus moradores experimentavam um viver "deprimente", com ruas e casas iguais em uma paisagem "[...] em tons de cinzento sujo" e "[...] tudo é muito mais escuro do que o norte ou o oeste da cidade, onde se situam as zonas 'boas"', temos de lembrar, como apontou Richard Hoggart para o caso inglês, que para os seus habitantes era o lugar onde "[...] a vida é vivida dentro de um grupo de ruas conhecidas, integrando-se numa vida de grupo muito intensa e ativa”. ${ }^{2}$ De fato, como nota Adriano Luiz Duarte, “[...] o bairro é, na realidade, um detalhe administrativo muitas vezes acidental e contingente", mas que se torna a "referência urbana" mais próxima das condições materiais de vida de seus habitantes. ${ }^{3}$

O bairro da Mooca foi oficialmente desmembrado do distrito do Brás em dezembro de 1910, ${ }^{4}$ ao mesmo tempo em que foram oficializados os bairros da Bela Vista, do Bom Retiro e da Lapa, o que sugere um esforço do poder público em regularizar em âmbito administrativo esses locais cuja existência era já recorrente na percepção e referências de seus moradores, e mencionados nos mapas e plantas de companhias públicas e privadas. Na lei que a oficializou, os limites geográficos da Mooca eram o rio Tamanduateí (oeste); as avenidas Rangel Pestana e Celso Garcia (norte); rua Bresser e rua Teffé, seguindo então pela rua da Mooca até o "valle do Tatuapé" (leste); córrego do "Allemão" até o "Morro da Mooca" (sul); e dali de volta ao rio Tamanduateí. ${ }^{5}$

Figura 1 - O bairro da Mooca em mapa de $1916 .^{6}$

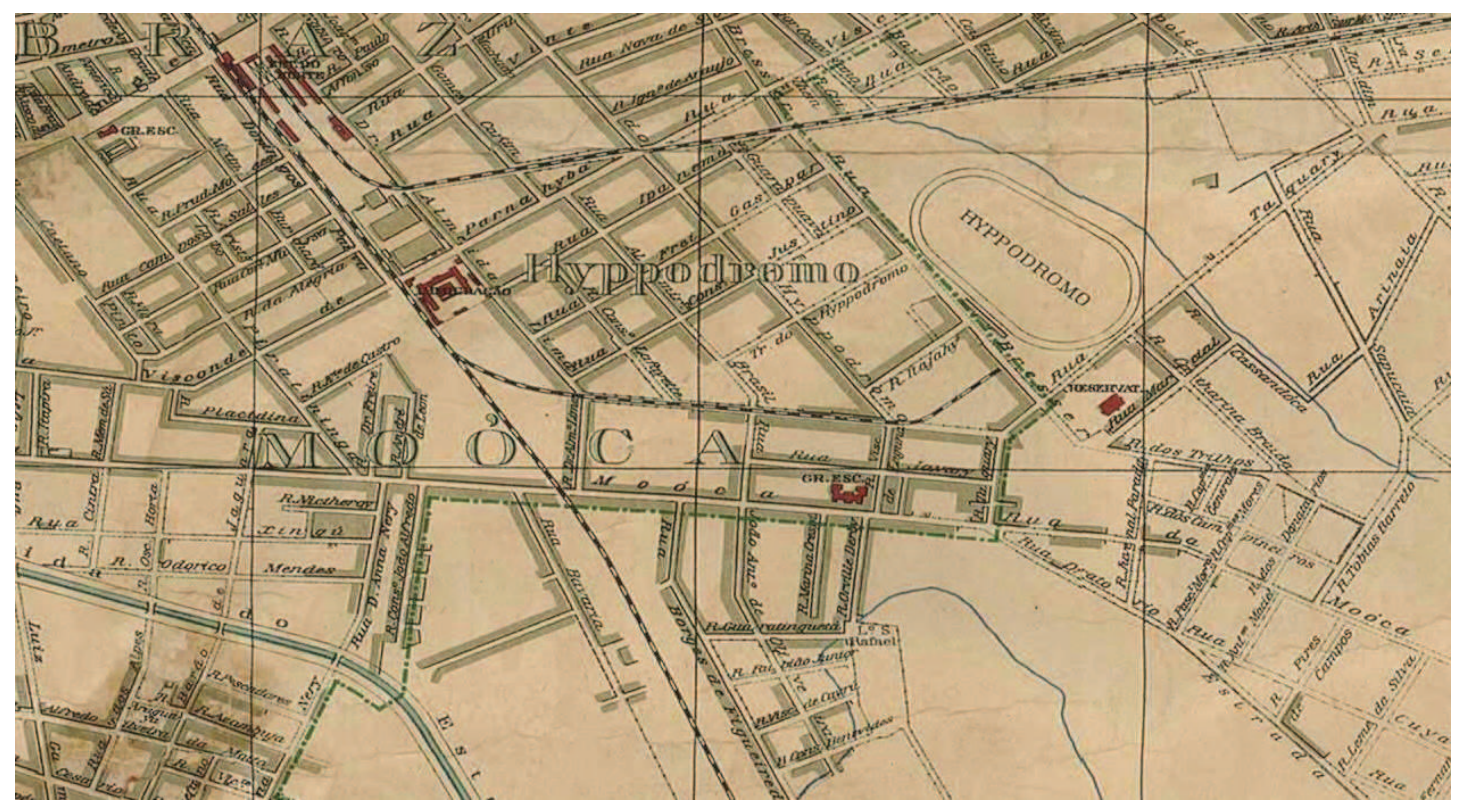

de Janeiro: Paz e Terra, 1987.

2 HOGGART, Richard. As Utilizações da Cultura: aspectos da classe trabalhadora, com especiais referências a publicações e divertimentos. v. 2. Lisboa: Presença, 1973, p. 72 e 77.

3 DUARTE, A. L. "Cultura popular e cultura política no após-guerra: redemocratização, populismo e desenvolvimentismo no bairro da Mooca, 1942-1973". (Tese de Doutorado, Universidade Estadual de Campinas, 2002), p. 3 .

4 Assembleia Legislativa do Estado de São Paulo (ALESP). Lei n. ${ }^{\circ} 1.237$ de 23 de dezembro de 1910.

5 RIBEIRO, José J. Repartição de Estatística e Archivo. Divisão administrativa e divisas municipaes do Estado

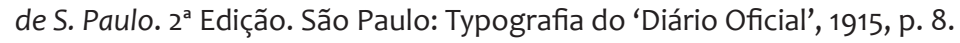

6 Planta da Cidade de São Paulo. Levantada pela Divisão Cadastral da $2^{a}$ Secção da Directoria de Obras e Viação da Prefeitura Municipal (“Edição Provisória”). Companhia Litographica Hartmann-Reichenbach, 1916. Disponível em: http://smdu.prefeitura.sp.gov.br/historico_demografico/. Acesso em: 1 de jun. 2015. 
É relevante lembrar, porém, que o bairro não está fechado em si mesmo, separado do restante da cidade. Os seus habitantes se deslocavam para além dessas fronteiras - nem sempre claras, mas espacialmente fluidas - para diversos fins, como trabalho, atividades sindicais ou diversão. E mesmo dentro destas fronteiras, não se pode supor uma identidade estanque, pois múltiplas identidades, como a local, mas também étnica, regional, de gênero, de ofício e de classe, se entrelaçavam e fundiam, se desfaziam e reconstruíam. ${ }^{7}$

É tarefa bastante difícil saber quantos eram os habitantes da Mooca antes de sua oficialização em 1910. Entretanto, sabemos que somavam, em 1916, 69.794 habitantes, sendo 35.957 homens e 33.837 mulheres, o que revela um relativo equilíbrio numérico entre os gêneros. Esse total fazia da Mooca já o bairro mais populoso da capital, seguido pelo Brás (66.086) e pelo Belenzinho (58.887). Em 1920, os moradores do bairro representavam $11,95 \%$ do total da capital, com 69.209 pessoas, número ainda superior ao dos vizinhos Brás (67.074) e Belenzinho (45.828), ${ }^{8}$ e substancialmente maior do que o do Bom Retiro, que contava naquele ano com 29.804. ${ }^{9}$

Outros elementos, contudo, inseriam a Mooca em um contexto comum a esses bairros. A sua população era formada na maior parte por estrangeiros, ${ }^{10}$ italianos em maioria, advindos do norte e do sul daquele país, mas também um expressivo contingente de espanhóis, e, posteriormente, imigrantes do centro e do leste europeu, como russos, lituanos, poloneses, húngaros e alemães, ${ }^{11}$ sugerindo uma viva multiplicidade identitária e cultural.

Inserida em um processo em que os mundos do trabalho urbano se estabeleciam, alargavam e diversificavam, a Mooca mostrava grande diversidade de atividade econômica e de ofícios. ${ }^{12} \mathrm{~A}$ exemplo do que ocorria em outros locais da cidade, como no Bom Retiro onde se encontrava uma grande quantidade de fábricas no ramo da tecelagem ${ }^{13}$, os estabelecimentos têxteis tinham forte presença no bairro. Estavam ali a Regoli, Crespi \& Comp., a Fábrica de Tecidos Labor, a Companhia de Indústrias Têxteis Penteado. Havia também empresas dos ramos de bebidas e de alimentação, como a Fábrica de Biscoitos Duchen, a Companhia Frigorífica Paulista, a Empresa de Laticínios União e a Fábrica de Bombons de Chocolate Optimus, a Distillação Italiana a Vapor, a Licores Azevedo e Barros e a fábrica de cerveja Bavária. Além destes, existiam estabelecimentos dedicados a outras atividades, como a Fábrica de Carros Rodovalho, a Fábrica de Calçados Clark, Companhia Paulista de Louça Esmaltada, e a Serraria Matarazzo. Fábricas e oficinas de menor vulto podiam também ser encontradas, sobretudo na rua da Mooca: fabriquetas de gaiolas, tamancos, carroças, fogos de artifício, pentes e bilhares; serrarias; carpintarias; tinturarias; oficinas mecânicas; ferrarias; lenharias.

7 SAVAGE, Mike. "Classe e história do trabalho". In: BATALHA, Claudio H. M. et al. (org.). Cultura de Classes: identidade e diversidade na formação do operariado. Campinas, SP: Editora Unicamp, 2004.

8 Ver SOUSA, Alberto. Estudos demográficos: a população de São Paulo no último decênio: 1907-1916. São Paulo: Tip. Piratininga, 1917, p. 90-91; e BRASIL. População do Brasil por Estados, municípios e distritos, segundo o sexo, a idade e a nacionalidade. v. IV. - $2^{\text {a }}$ Parte. Tomo I, 1926. Ministério da Agricultura, Indústria e Comércio, p. 122-139. Disponível em: http://biblioteca.ibge.gov.br/visualizacao/livros/liv6461.pdf. Acesso em: 1 de jun. 2015.

9 SIQUEIRA, Uassyr. "Clubes e Sociedades dos Trabalhadores do Bom Retiro: organização, lutas e lazer em um bairro paulistano (1925-1942)”. (Dissertação de mestrado, Universidade Estadual de Campinas, 2002), p. 40.

10 HALL, Michael. "Imigrantes na cidade de São Paulo". In: PORTA, Paula (org.). História da Cidade de São Paulo: a cidade na primeira metade do século XX. (v. 3). São Paulo: Paz e Terra, 2004, p. 121.

11 DUARTE. "Cultura popular e cultura política no após-guerra", p. 201; e CANOVAS, M. D. K. Imigrantes Espanhóis na Pauliceia: Trabalho e Sociabilidade Urbana (1890-1922). São Paulo: Edusp: FAPESP, 2009.

12 Utilizei neste levantamento, sobretudo, BANDEIRA JUNIOR, A. F. A Indústria no Estado de São Paulo em 1901. São Paulo: Typografia do 'Diário Oficial', 1901; e a coleção do jornal Correio Paulistano (1900-1920).

13 SIQUEIRA. "Clubes e Sociedades dos Trabalhadores do Bom Retiro", p. 38. 
A partir desse elenco de fábricas e oficinas, podemos deduzir o ofício dos habitantes do bairro, além de outras profissões, como pedreiros, pintores, carroceiros, cocheiros, vendedores ambulantes, empregados em serviços domésticos (estes normalmente ocupados por trabalhadores negros, com menores salários $\left.^{14}\right)$, que não se empregavam diretamente nessas fábricas, mas que habitavam e trabalhavam no bairro. ${ }^{15}$ Toda essa diversidade indica uma convivência de trabalhadores com ofícios mais ou menos especializados e com diferentes salários, o que podia gerar disputas ou divisões.

As condições de vida encontradas no bairro, contudo, eram uma experiência comum à grande maioria dos trabalhadores. As más condições de habitação - ou a falta de moradia -, a escassez de água, esgoto, luz, além das constantes enchentes que o bairro enfrentava, e de salários muitas vezes insuficientes para uma alimentação adequada, fazia com que os habitantes ficassem vulneráveis a doenças de todo tipo. ${ }^{16}$

O quadro que se abre é bastante revelador da grande heterogeneidade e complexidade das relações sociais dos habitantes do bairro: ao mesmo tempo em que possibilitava uma multiplicidade cultural e identitária, fazia emergir padrões comuns às experiências dos trabalhadores da Mooca.

\section{Um panorama associativo da Mooca}

Diante dessa multiplicidade cultural e identitária encontrada do no bairro da Mooca, assim como no restante da cidade de São Paulo, a sociabilidade dos trabalhadores apresentava diversas possibilidades. Já há muito tempo, sindicatos e ligas, apesar de sua inegável importância, não são mais considerados os únicos lugares possíveis de organização dos trabalhadores. ${ }^{17}$ Os estudos sobre a sociabilidade dos trabalhadores, sobretudo sobre o mutualismo, como demonstra Cláudia Viscardi, ${ }^{18}$ vem ganhando importância nas últimas décadas, em um esforço de revelar nessas associações a sua contribuição no processo de formação da classe operária. Luigi Biondi demonstra que as experiências nas associações mutualistas italianas, longe de compor um quadro homogêneo, eram bastante dinâmicas, articulando através de uma multiplicidade de intervenções sentimentos como o de pertencimento étnico e de classe, tornando o mundo associativo dos trabalhadores em um ambiente bastante complexo. ${ }^{19}$ Também as associações recreativas se tornaram objeto de investigação na busca por lugares em que uma consciência de classe poderia se manifestar. Essas sociedades, cujo

14 Ver TRINDADE, Liana S. “O negro em São Paulo no período pós-abolicionista”. In: PORTA. História da Cidade de São Paulo.

15 Ver PINTO, Maria I. M. B. Cotidiano e Sobrevivência: A Vida do Trabalhador Pobre na Cidade de São Paulo, 1890-1914. São Paulo: Editora da Universidade de São Paulo, 1994, p. 74 e 83.

16 GUZZO. A Vida Fora das Fábricas, p. 39.

17 Ver BATALHA, Claudio H. M. "Cultura associativa no Rio de Janeiro da Primeira República”. In: BATALHA. Cultura de Classes, p. 95-120; BIONDI, Luigi. Classe e Nação: trabalhadores e socialistas italianos em São Paulo (1890-1920). Campinas-SP: Editora da Unicamp, 2011; SIQUEIRA. "Clubes e Sociedades dos Trabalhadores do Bom Retiro" e "Entre sindicatos, clubes e botequins: identidades, associações e lazer dos trabalhadores paulistanos (1890-1920)". (Tese de doutorado. Universidade Estadual de Campinas, 2008); TRENTO, Angelo. "Organização Operária e Organização do Tempo Livre entre os Imigrantes Italianos em São Paulo". In: CARNEIRO, Maria L. T. [et al.]. História do Trabalho e História das migrações: Trabalhadores Italianos e Sindicatos no Brasil (Séculos XIX e XX). São Paulo: Edusp: Fapesp, 2010. p. 233-266.

18 VISCARDI, Cláudia. M. R., "O estudo do mutualismo: algumas considerações historiográficas e metodológicas". Revista Mundos do Trabalho, v. 2, p. 23-39, 2010.

19 BIONDI. Classe e Nação. 
objetivo era proporcionar àquelas pessoas diversas modalidades de recreação musicais, teatrais, esportivas, educativas -, desempenhavam um papel relevante, proporcionando acesso à informação, ao letramento e à cultura, e também eram espaços onde podiam experimentar um viver coletivizado, auxiliarem-se e construir uma rede de solidariedade. ${ }^{20}$ Assim, alargar as abordagens para as diversas formas de associativismo dos trabalhadores abria novos horizontes para a compreensão dos processos de sociabilidade e de organização, em que se entroncavam múltiplas identidades - étnica, regional e de classe. ${ }^{21}$

Na cidade de São Paulo, já desde o fim do século XIX, os trabalhadores constituíam associações de diversos tipos e com diversas finalidades. No limiar dos anos 1900 o panorama das associações da cidade se transformava e as que foram fundadas a partir de então estavam inseridas em um processo em que bairros como Bom Retiro, Barra Funda, Lapa, Cambuci e Mooca tornavam-se os locais privilegiados de instalação de sedes dessas sociedades. ${ }^{22}$

Dirigindo a nossa atenção para as associações surgidas, ou que se instalaram depois, no bairro da Mooca entre os anos de 1900 e 1920, conseguimos encontrar ao todo 65 associações, a partir de diferentes fontes. É fato que por muitas vezes esses documentos se limitam à menção ao nome da sociedade e, em alguns casos, o mencionam por uma única vez, dificultando a tentativa de mapeamento. Entretanto, buscamos entre jornais de matizes políticas diferentes, além de outros, em um esforço para cobrir diferentes tipos de associações que poderiam ficar de fora se nos limitássemos a um só periódico. Além disso, ampliamos a pesquisa para outros documentos, como almanaques, anuários estatísticos e, sobretudo, os estatutos de sociedades civis. A partir do cruzamento das informações obtidas, encontramos as seguintes sociedades:

Tabela 1 - Associações encontradas na Mooca com o ano de fundação ou de surgimento. ${ }^{23}$

\begin{tabular}{c|c}
\hline Associação & Ano \\
\hline Unione Meridionale Italiana (Meridionale Uniti) & 1896 \\
\hline Sport Club Germânia & 1899 \\
\hline Società Italiana di Mutuo Soccorso Unionedella Mooca & 1900 \\
\hline Sociedade Beija-Flor & 1902 \\
\hline Sociedade Brasil & 1902 \\
\hline Club Recreativo Mocidade Mooca & 1904 \\
\hline
\end{tabular}

20 SIQUEIRA. "Clubes e Sociedades dos Trabalhadores do Bom Retiro" e "Entre sindicatos, clubes e botequins".

21 BIONDI, Luigi. "Imigração Italiana e Movimento Operário em São Paulo: Um Balanço Historiográfico”. In: CARNEIRO. História do Trabalho e História das Migrações, p. 23-48.

22 Ver BIONDI. Classe e Nação.

23 Os documentos utilizados para este mapeamento são: coleções dos jornais Fanfulla (1898-1920); Correio Paulistano (1900-1919 e 1920-1929); O Combate (1917-1927); O Commercio de São Paulo (1983-1909); Diario Español (1912-1922); A Lanterna (1909-1916); coleção dos Estatutos das Sociedades Civis, Apesp (1896-1922); Diário Oficial do Estado de São Paulo (1895-1921); Anuário Estatístico do Estado de São Paulo (1898-1920); Almanacco illustrato della "Tribuna Italiana". San Paolo: Tribuna Italiana, UFFCl, 1905; Almanach para 1916. São Paulo, O Estado de São Paulo, 1916; Almanach da Secretaria de Estado dos Negócios da Agricultura, Commercio e Obras Públicas do Estado de São Paulo para o anno de 1917. São Paulo: 1917. O clube de futebol Cinco de Outubro foi encontrado em uma referência na obra de Jacob Penteado, Belenzinho, 1910: retrato de uma época. São Paulo: Carrenho Editorial/Narrativa Um, 2003, p. 203. As informações sobre o Sport Club Germânia e o Ítalo Brasileiro foram retiradas de SALUM, Alfredo Oscar. Palestra Itália e Corinthians: Quinta Coluna ou Tudo Buona Gente? (Tese de Doutorado. Universidade de São Paulo, 2007), p. 32. 
Continuação

\begin{tabular}{|c|c|}
\hline Sociedade Dançante Recreativa da Mooca & 1904 \\
\hline Sport Club Athletico Mooca & 1904 \\
\hline Società Ricreativa Stella d'Italia & 1905 \\
\hline Sport Club Mocidade da Mooca & 1905 \\
\hline Società Ricreativa Stella d'Italia' ${ }^{1}$ & 1906 \\
\hline Sociedade Cooperativa dos Cocheiros & 1907 \\
\hline Associação Recreativa Athletica da Mooca & 1908 \\
\hline Circolo Filodrammatico Tina di Lorenzo & 1908 \\
\hline Circolo Ricreativo Filodrammatico Matteo Renato Imbriani & 1909 \\
\hline Club Recreativo Foot-Ball & 1909 \\
\hline Sociedade Recreativa Giovanni Zanatello & 1909 \\
\hline Cinco de Outubro F. B. C. & 1910 \\
\hline Italo Brasileiro Foot-Ball Club da Mooca & 1910 \\
\hline Banda União Operária & 1911 \\
\hline Escola Allemãn Mooca e Braz & 1911 \\
\hline Sport Club Flor da Mooca & 1911 \\
\hline Círculo de Estudos Sociaes Francisco Ferrer & 1912 \\
\hline Club Infantil Flor da Mooca & 1912 \\
\hline G. D. I. Libertário & 1914 \\
\hline Guttemberg Foot-Ball Club & 1914 \\
\hline Sport Club Infantil Internacional & 1914 \\
\hline Royal Recreativo da Mooca & 1914 \\
\hline Conferência de San Gennaro & 1914 \\
\hline Sociedade Internacional Beneficente de São Paulo & 1914 \\
\hline Associação Universidade Popular de Cultura Racionalista & 1915 \\
\hline Centro Feminino Jovens Idealistas & 1915 \\
\hline Escola Nova & 1915 \\
\hline Grêmio Dramático 15 de Novembro & 1915 \\
\hline Oriental Mooca Foot-Ball Club & 1915 \\
\hline União Geral dos Trabalhadores & 1915 \\
\hline Circolo Ricreativo Savoia Vincit & 1916 \\
\hline Gruppo Filodrammatico e Ricreativo Mooca & 1916 \\
\hline Sociedade Internacional de Socorro Mútuo da Mooca & 1916 \\
\hline Società Ricreativa Danzante Fiore della Mooca & 1916 \\
\hline Società Drammatica Ricreativa e Sportiva Stella d'Italia & 1916 \\
\hline Centro Libertário da Mooca & 1917 \\
\hline Liga Operária da Mooca & 1917 \\
\hline Liga dos Operários de Tecelagem da Mooca & 1917 \\
\hline Sociedade Recreativa Musical da Mooca & 1917 \\
\hline Sport Club Juventude & 1917 \\
\hline Associação dos Operários em Fábricas de Tecidos da Mooca & 1918 \\
\hline
\end{tabular}




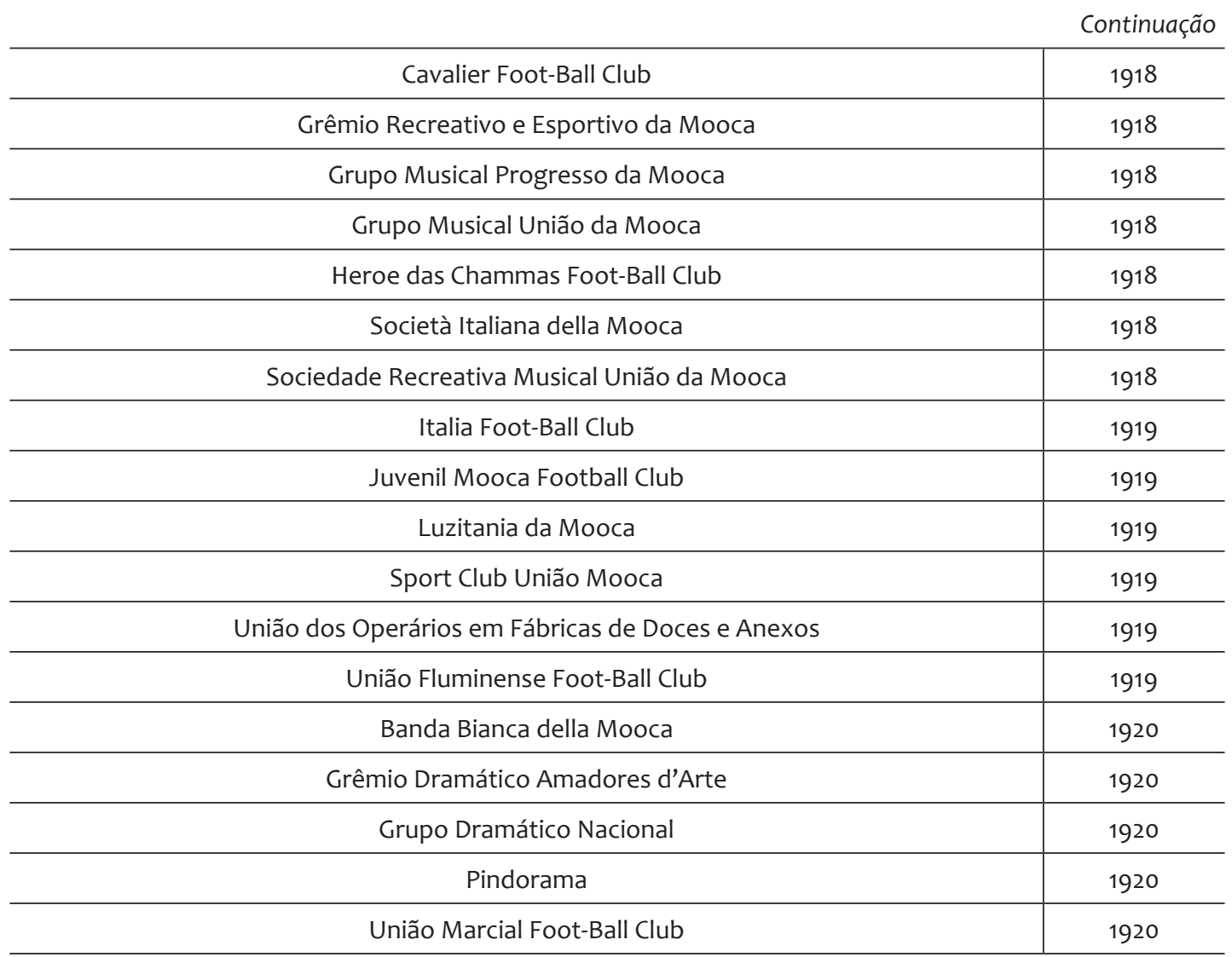

O elenco de associações exposto acima, o leitor deve já ter notado, traz duas sociedades cujo surgimento antecede o período proposto, mas isso se explica por possibilitar uma análise mais global do fenômeno associativo na Mooca, além do que, a existência tanto da Meridionali quanto do Sport Club Germânia adentra o recorte temporal aqui proposto.

O S. C. Germânia, é importante esclarecer, mesmo sendo uma associação fundada na Mooca por imigrantes, era composta de forma quase exclusiva por filhos de comerciantes alemães proprietários de estabelecimentos de maior vulto, ${ }^{24}$ tornando a sociedade um local marcadamente frequentado por camadas mais abastadas da sociedade, afastando-a daquelas fundadas entre os trabalhadores. $\mathrm{O}$ mesmo se aplica ao conhecido Jockey Club. Na verdade, como se pode perceber, o Jockey - cuja relação com o bairro da Mooca é evidente, já que as costumeiras corridas de cavalos eram realizadas no hipódromo situado justamente na rua que levou o nome da atração, a rua do Hipódromo - não foi elencado entre as associações da Mooca, e isso por um motivo: a sua sede situava-se na região central da cidade, à rua XV de Novembro, onde o clube mantinha uma sala para leituras e palestras e outra para diversões com jogos lícitos, como bilhares. Além disso, o Jockey Club era um local exclusivo das famílias abastadas da sociedade paulistana, um exclusivismo que barrou por algum tempo até mesmo a entrada de imigrantes enriquecidos, como proprietários de grandes indústrias e do comércio. ${ }^{25}$ Desta forma, as duas associações - o Jockey Club e o S. C. Germânia se excluem daquelas sobre as quais desejamos manter a nossa atenção neste texto, isto é, as associações dos trabalhadores comuns do bairro da Mooca.

25 RAGO, Margareth. "A invenção do cotidiano na metrópole: sociabilidade e lazer em São Paulo, 1900-1950". In: PORTA. História da Cidade de São Paulo, pp. 387-436. 
Voltando agora à listagem, conseguimos traçar, ao aglutinar as informações encontradas, um quadro das fundações, instalações ou primeira menção encontrada sobre as sociedades.

Tabela 2 - Quantidade de associações surgidas no bairro da Mooca entre 1896 e 1920.

\begin{tabular}{c|c|c|c}
\hline Ano & Associações & Ano & Associações \\
\hline 1896 & 1 & 1910 & 2 \\
\hline 1899 & 1 & 1911 & 3 \\
\hline 1900 & 1 & 1912 & 2 \\
\hline 1902 & 2 & 1914 & 6 \\
\hline 1904 & 3 & 1915 & 6 \\
\hline 1905 & 2 & 1916 & 5 \\
\hline 1906 & 1 & 1917 & 5 \\
\hline 1907 & 1 & 1918 & 8 \\
\hline 1908 & 2 & 1919 & 5 \\
\hline 1909 & 3 & 1920 & \\
\hline
\end{tabular}

Com os dados expostos acima, podemos notar que entre 1896, ano de fundação da primeira sociedade encontrada no bairro, até o início da década de 1910 o número de associações surgidas oscilou entre 1 e 3. Essa baixa quantidade de fundações anuais de sociedades pode se explicar tanto pelas duras condições materiais que os trabalhadores enfrentavam naquele período de baixos salários, o que tornava menor a destinação dos escassos recursos à manutenção de associações, quanto pelas dificuldades de organização dos trabalhadores encontradas inclusive por militantes do movimento operário. A partir de 1914, contudo, percebe-se um aumento significativo de sociedades surgindo no bairro, totalizando 6 naquele ano, e outras 6 em 1915, período marcado por uma retomada do empenho sobre a organização dos operários por parte de socialistas, anarquistas e sindicalistas revolucionários. ${ }^{26}$ Entre 1916 e 1917 a quantidade permaneceu praticamente a mesma, com 5 associações fundadas em cada ano.

É interessante de se notar o substancial aumento na fundação de sociedades em 1918, ano em que encontramos 8, pois aquele foi um período marcado pela gripe espanhola e pelo agravamento da repressão sobre as associações de trabalhadores. Aquele era também um momento em que as ligas e os sindicatos se reavivavam e tentavam se solidificar. Contudo, a repressão se intensificou ainda mais nos anos seguintes em termos de violência policial e por muitas vezes a polícia invadiu e fechou as sedes de associações de trabalhadores, ${ }^{27}$ o que pode ajudar a explicar a redução no número de associações fundadas em 1919 e 1920.

O tempo de existência da maior parte das sociedades de trabalhadores foi efêmero. As dificuldades em manter ativa uma associação, incluídas aí a falta de recursos e a repressão policial, eram bastante sensíveis. Além disso, processos de reformulação, fusões e mudanças de nome tinham relevante impacto no seu desaparecimento. Ao todo 40 sociedades não ultrapassaram o primeiro ano de vida. Todavia, algumas agremiações chegaram a superar os 5 anos de duração, e outras

26 BIONDI. Classe e Nação.

27 HALL, Michael. "O Movimento Operário na Cidade de São Paulo: 1890-1954", p. 259-289. 
ainda existiram por mais de 20 anos. As sociedades que conseguiram ultrapassar o primeiro ano de existência são: Unione Meridionale Italiana (1896-1908); S. O. M. S. Unionedella Mooca (1900-1904); S. C. Athletico Mooca (1904-1909); S. R. Stella d'Italia (1905-1908); S. R. Stella d'Italia (1906-1909); A. R. Athletica da Mooca (1908-1920); Escola Allemãn Mooca e Braz (1911-1921); Círculo de Estudos Sociaes Francisco Ferrer (19121915); União Geral dos Trabalhadores (1914-1916); Conferência de San Gennaro (19141919); S. R. Danzante Fiore della Mooca (1916-1919); S. Internacional de S. M. da Mooca (1916-1936); S. R. Musical da Mooca (1917-1928); S. Italiana della Mooca (1918-1940).

Quando cruzamos todas essas informações, conseguimos ter uma boa noção da coexistência de associações no bairro entre 1900 e $1920 .^{28}$ Tabela 3 - Número de associações em funcionamento anualmente no bairro da
Mooca.

\begin{tabular}{|c|c|c|c|c|c|}
\hline Ano & $\begin{array}{l}\text { Sociedades em } \\
\text { funcionamento }\end{array}$ & Ano & $\begin{array}{l}\text { Sociedades em } \\
\text { funcionamento }\end{array}$ & Ano & $\begin{array}{l}\text { Sociedades em } \\
\text { funcionamento }\end{array}$ \\
\hline 1900 & 2 & 1907 & 5 & 1914 & 9 \\
\hline 1901 & 2 & 1908 & 6 & 1915 & 11 \\
\hline 1902 & 4 & 1909 & 7 & 1916 & 11 \\
\hline 1903 & 2 & 1910 & 4 & 1917 & 9 \\
\hline 1904 & 5 & 1911 & 4 & 1918 & 14 \\
\hline 1905 & 4 & 1912 & 4 & 1919 & 16 \\
\hline 1906 & 4 & 1913 & 3 & 1920 & 10 \\
\hline
\end{tabular}

Ao observar a tabela acima, podemos perceber que entre 1900 e 1903, com uma pequena variação em 1902, havia 2 associações no bairro, número se deve possivelmente à piora nas condições de vida do período, aliada a uma grave crise de desemprego, o que certamente dificultava a manutenção de associações. ${ }^{29}$ Naquele período havia duas associações mutualistas e as sociedades recreativas, que surgiram em 1902, deixaram de existir ainda no mesmo ano em que foram fundadas. A partir de 1904 a quantidade de associações atuantes sobe para 5, com uma pequena queda nos anos 1905 e 1906, mas retomando a mesma quantidade em 1907.

É preciso notar, levando em conta não apenas a tabela acima, mas também a listagem de associações disposta anteriormente, que o aumento no número de sociedades se deu entre as associações recreativas em geral - das associações que existiam em 1904, 3 eram recreativas. Ainda em 1904 a S. O. M. S. Unione della Mooca deixou de existir. E nos anos de 1905 e 1906 se encontravam ativas, além da Meridionali Uniti, apenas agremiações recreativas. Em 1907 o quadro se mantém praticamente o mesmo, a não ser pelo surgimento naquele ano da Sociedade Cooperativa dos Cocheiros de São Paulo.

Apesar das grandes greves ocorridas em 1907, o movimento sindical entrou em declínio ${ }^{30}$ e, desta forma, não deve surpreender que até 1912 as associações presentes na Mooca fossem todas voltadas à recreação. De toda forma, entre

28 Excetuando-se, como mencionado anteriormente, o S. C. Germânia e o Jockey Club.

29 BIONDI. Classe e Nação, p. 180.

30 HALL, Michael; PINHEIRO, Paulo Sérgio. (Org.). A Classe Operária no Brasil. 1899-1930. Vol. I. São Paulo: AlfaOmega, 1979, p. 114. 
1910 e 1913 - curiosamente, já que 1910 foi o ano da oficialização do bairro a quantidade de sociedades sofre uma queda. Para o movimento operário da época tratava-se de um período de completa letargia, afirmação esta que se baseava na forte redução das atividades das ligas de ofício. Além disso, apesar de uma melhoria no mercado de trabalho, a redução pode ser explicada por ser aquele um período de aumento no custo de vida. É somente após 1914 que o associativismo no bairro ganha um maior fôlego. Entre 1914 e 1916 a quantidade de associações parece se estabilizar, muito por causa da retomada das atividades sindicais e políticas. ${ }^{31} \mathrm{Em} \mathrm{1914}$, das 9 associações existentes, 3 estavam ligadas de forma mais direta ao movimento operário - o G. D. I. Libertário, o C. E. S. "Francisco Ferrer" e a Sociedade Internacional Beneficente de São Paulo -, mesmo número das recreativas, além de 1 educativa, 1 esportiva e 1 ligada à Paróquia de San Gennaro. Nos anos de 1915 e 1916 instalaram-se no bairro a União Geral dos Trabalhadores e as escolas libertárias Escola Nova e a Universidade Popular Racionalista, além de outras sociedades recreativas. Em 1917 as associações existentes são praticamente as mesmas dos dois anos anteriores e a redução que observamos naquele ano da grande greve geral se deve principalmente à descontinuidade das escolas libertárias e à concentração dos trabalhadores em torno da U. G. T., esta que daria vez à Liga Operária da Mooca. Contudo, neste mesmo período, o aparato repressivo era diversificado e modernizado pelo Estado e pelos empresários, mesclando violência, prisões e um esforço maior daqueles últimos em ordenar o lazer dos trabalhadores. Muito em função disto, o número de sociedades volta a cair a partir de 1920, marcando um refluxo na organização dos trabalhadores que adentraria a década seguinte. ${ }^{32}$

Quando observamos a listagem inicial de sociedades encontradas na Mooca (Tabela 1), um outro aspecto que se revela é a diversidade associativa que os trabalhadores encontravam. Havia no bairro uma grande variedade de associações dedicadas a diversos fins, como mutualistas (S. M. S.), sindicais e políticas, assim como sociedades recreativas, musicais, teatrais, esportivas e educativas.

Se nos referimos a diferentes tipos de associações, é necessário nos deter sobre a sua definição. É importante frisar que com uma "definição" não pretendemos separar cada sociedade em mundos associativos apartados entre si, invisíveis uns aos outros e aos trabalhadores do bairro. Contudo, sem esta organização poderíamos homogeneizar experiências associativas bastante diferentes e terminaríamos por afirmar um monopólio sobre a organização dos trabalhadores que a historiografia tradicional atribuiu a partidos, sindicatos e associações explicitamente políticas, estas que foram importantíssimas nas lutas e na própria organização, mas não eram as únicas a agirem entre os trabalhadores. Assim, correríamos o risco de cair no erro sobre o qual E. P. Thompson nos alertou em seu estudo sobre a classe operária inglesa - tomando aqui a liberdade de usar suas palavras para o nosso caso -, em que desvendaríamos a recreação e o associativismo "[...] não como é, mas “como deveria ser'". 33 E a nossa pretensão de indicar as associações por tipo é justamente mostrar que a experiência associativa dos trabalhadores do bairro da Mooca era dinâmica e diversificada.

Isto posto, entendemos que uma organização em tipos deva respeitar, antes de tudo, a forma como as próprias agremiações se definiam. Portanto, tomamos por

31 Ver BIONDI. Classe e Nação, p. 284 e 327.

32 HALL. "O Movimento Operário na Cidade de São Paulo", p. 280-281.

33 THOMPSON, E. P. A Formação da Classe Operária Inglesa. v. 1. Rio de Janeiro: Paz e Terra, 1987, p. 10. 
"recreativas" aquelas agremiações que claramente se apresentavam assim, como "Sociedades Recreativas", "Recreativas Musicais" ou "Musicais Recreativas", "Recreativas Dançantes" ou "Dançantes Recreativas", "Recreativas Dramáticas" e vice-versa, "Recreativas atlético-esportivas", enfim, que apresentavam características de recreação em geral, mas também as que as intenções não estavam aparentes em seus nomes, mas que demonstravam o seu interesse em oferecer uma recreação que incluísse práticas diversas. Chamamos "esportivas" aquelas sociedades cujas práticas eram voltadas predominantemente ao esporte, e, claro, as que normalmente carregavam em seu nome tal indicação, como indicavam as iniciais "F. C." (Futebol - ou Football - Clube) e "F. B. C" (Foot Ball Club), ou ainda "S. C." (Sport Club) e "A. C." (Athletic Club), ou também a versão em língua portuguesa "C. A." (Clube Atlético) e assim por diante. Consideramos "Musicais" aquelas que se intitulavam "Banda" ou "Grupo Musical", mas também as dedicadas principalmente às performances musicais. No tipo "Teatrais" incluímos grêmios, grupos e sociedades autodenominadas "Dramática" ou "Filodramática". As "Educativas" (Escola, Círculo, etc.) eram aquelas que tinham por objetivo a educação e o desenvolvimento cultural, e também a partir desses objetivos foram consideradas "educativas" aquelas que não tinham essa prática ou objetivo explicitados em seu nome.

Entre aquelas cujos objetivos não eram voltados diretamente para o lazer e recreação, consideramos como "religiosas" as associações ligadas às igrejas. $\mathrm{Na}$ Mooca o único caso desse tipo que encontramos foi o da Conferência de San Gennaro, cujo nome por si é bastante sugestivo. Se insistimos em classificá-la como um tipo "religioso" de sociedade (por falta de termo melhor) é por sua óbvia ligação com a paróquia famosa do bairro, dedicada a San Gennaro.

Entre as "Sociedades de Mútuo Socorro", incluímos aquelas que assim se definiam, mas também as que tinham por objetivo principal a proteção de seus sócios por meio de beneficência e cooperativas, fosse por etnia ou por ofício. As associações que apresentavam como característica principal a de organização por ofício ou por vários ofícios para defesa ou melhorias econômicas de seus associados foram elencadas sob o tipo "sindicais". Por fim, classificamos entre as "políticas" os grupos que desenvolviam ações voltadas diretamente à sensibilização e despertar dos trabalhadores. ${ }^{34}$

Algumas observações sobre essas definições, porém, devem ser feitas. As associações que exibiam a palavra "círculo" em sua nomenclatura nem sempre se encaixavam entre as educativas, o que seria o caso se fossemos seguir uma classificação realizada somente a partir dos nomes, pois trata-se, o "círculo", de um termo que indica como principal finalidade a difusão cultural. 35 O Circolo Filodrammatico Tina di Lorenzo, por exemplo, figura entre as associações teatrais, pois era dedicado à esta prática, assim como o Circolo Ricreativo Filodrammatico Matteo Renato Imbriani. O Circolo Ricreativo Savoia Vincit também não se enquadrava entre as sociedades educativas, mas sim entre as recreativas em geral, pois as suas atividades principais eram as festas com música e bailes. ${ }^{36}$

Outro caso que se assemelha aos anteriores é o da Sociedade Recreativa

34 Terminologia parecida já foi utilizada para classificar "associações partidárias" e "grupos anarquistas", entre outros, no estudo sobre associações de trabalhadores do Bom Retiro, de Uassyr de Siqueira, ainda que no caso daquele bairro, como aponta o autor, estivessem ausentes tais tipos de sociedades. Ver SIQUEIRA. "Clubes e Sociedades dos Trabalhadores do Bom Retiro", p. 51.

35 BIONDI. Classe e Nação, p. 56.

36 Ver as edições do Fanfulla de 12 e 15/02/1909 e 11/05/1916. 
Musical União da Mooca, que apesar de usar o termo "recreativa", o que sugeriria a adoção de diversas modalidades de práticas recreativas, mantinha a sua atenção predominantemente voltada às atividades musicais, tratando-se na verdade de uma banda musical, além de ter esta sociedade surgido a partir da fusão de dois grupos musicais, a Banda União da Mooca e a Banda Progresso da Mooca, em 1918. ${ }^{37}$

Atribuir às sociedades uma classificação a partir da predominância de uma prática de recreação, todavia, não significa que as associações realizassem somente uma modalidade exclusiva. É importante ter em mente, ainda, que as atividades de lazer não se limitavam ao âmbito das sociedades recreativas. Como exemplo, a U. G. T., associação de caráter abertamente sindical, realizava suas festas com apresentações teatrais - marcadas, no caso desta sociedade, pelo teor crítico à ordem vigente da sociedade -, música, baile e quermesse..$^{38} \mathrm{O}$ C. E. S. Francisco Ferrer, de caráter educativo e político, além das costumeiras palestras e aulas, realizava reuniões comemorativas em datas consideradas importantes ao grupo, como o Primeiro de Maio, e diversas festas de propaganda, que contavam com baile e música, além das quermesses. ${ }^{39}$ Também as associações mutualistas não deixavam de realizar as suas festas, com danças, música, teatro e bailes para comemorar o aniversário de fundação, inaugurar suas sedes ou para proporcionar algum divertimento aos sócios. ${ }^{40}$

Um outro fator a ser notado a partir da listagem inicial é que muitos dos nomes de associações da Mooca indicam um sentimento de pertencimento étnico. Entre elas, as italianas eram a maioria, seguindo a composição mesma do bairro. Além dessas, havia apenas uma alemã, a Escola Allemãn Mooca e Bráz, e uma portuguesa, a Luzitania da Mooca, sobre a qual sabemos pouquíssimo. Aquelas cuja nomenclatura aponta para a origem italiana de seus sócios são: Banda Bianca della Mooca; C. R. Savoia Vincit; Circolo Filodrammatico Tina di Lorenzo; Circolo Recreativo Filodrammatico Matteo Renato Imbriani; Gruppo Filodrammatico e Ricreativo Mooca; Italia Foot Ball Club; Sociedade Italiana della Mooca; Sociedade Operaria de M. S. Unione della Mooca; Sociedade Recreativa Giovanni Zanatello; as duas Sociedade Recreativa Stella d'Italia; Società Drammatica Ricreativa e Sportiva Stella d'Italia; Società Ricreativa Danzante Fioredella Mooca; e Società Unione Meridionali Uniti.

A escolha do nome da associação, longe de ser entregue ao acaso, como adverte Luigi Biondi, indicava uma gama de sentimentos. O caráter mais localista, reforçado pelas nomenclaturas adotadas, podia representar um duplo papel: o de demonstrar que imigrantes, sobretudo advindos do sul italiano, tinham um espaço relevante na comunidade imigrada; e o de marcar uma identidade política, umas aproximando-se do monarquismo - como no caso da Unione Meridionale Italiana (União Meridional) -, outras associando a identidade italiana (isto é, mantendo-se fiel ao recém surgido Estado italiano) a uma identidade de classe. ${ }^{41}$

Algumas dessas sociedades homenageavam personagens de suas regiões, como é o caso do C. R. F. Matteo R. Imbriani, que emprestou o nome de uma figura importante nascida em Nápoles, capital da Campânia. Neste caso, entretanto, pode-se sugerir também um tipo de entroncamento identitário, pois parece ser tanto regionalista quanto uma busca pela união entre italianos, já que Matteo R.

37 Fanfulla, 23/02/1918 e 01/10/1918.

38 Fanfulla, 15/04/1916.

39 A Lanterna, 16/03/1912 e 06/05/1912.

40 Por exemplo a S. Cooperativa dos Cocheiros, a S. Internacional de S. M. da Mooca e a Società Operaia di M. S. Unione della Mooca, no Fanfulla de 05/09/1907, 11/12/1920 e 02/01/1901, respectivamente.

41 BIONDI. Classe e Nação, p. 73 e 74. 
Imbriani integrou o movimento irredentista, que tinha por objetivo a unificação de regiões italianas sob o domínio da Áustria com a Itália, ${ }^{42}$ o que poderia significar uma abertura para que italianos provenientes de diversas regiões, e não somente da meridional, ingressassem na associação. Giovanni Zanatello, tenor italiano nascido em Verona, região do Vêneto, foi homenageado pela sociedade recreativa que levou seu nome, e Tina di Lorenzo, proeminente atriz italiana nascida na capital da região piemontesa, Turim, emprestou seu nome a um círculo filodramático.

Ainda que os nomes escolhidos sugiram a presença de italianos nessas sociedades, somente a partir desta observação não se pode lançar nenhum tipo de afirmação quanto à exclusividade de sua presença ou que essas associações tinham como critério associativo a etnia. A composição da diretoria do C. R. F. Matteo R. Imbriani, por exemplo, apresentava sócios com origens em diversas regiões da Itália, além de um membro não italiano. Em 1910, Ciro Aliperbi era o presidente, Giuseppe Fuscellio seu vice; José Zeverner e Olivio Ferrari os secretários; Luigi Gregnanica o caixa; Francesco La Vecchia, Attilio Pavanelli, Ciro Vittolo e Nunziato Labatti os conselheiros; Pietro Molari e Luigi Martinelli os revisores; Antonio Di Marco e Vincenzo Vietri, primeiro e segundo mestre de sala; Giuseppe Romano e Antonio Portiello, primeiro e segundo fiscal, respectivamente. ${ }^{43}$ Percebe-se no conselho formado de uma maioria de italianos, cujos sobrenomes sugerem origem meridional (Campânia principalmente) e setentrional (Emilia-Romagna e Lombardia, principalmente), o nome de José Zeverner, este possivelmente alemão.

Os vínculos identitários que se podiam criar nas associações da Mooca são bastante variados, sugerindo uma dinâmica associativa ainda mais intrincada. Além disso, alia-se a esse cenário um forte interassociativismo, em que os trabalhadores podiam participar ao mesmo tempo de mais de uma associação, transitando, por exemplo, entre as sociedades mutualistas, sindicais e recreativas, conformando diversas interconexões associativas e revelando uma grande mobilidade na sociabilidade dos trabalhadores. ${ }^{44}$ Assim, o mundo associativo do bairro, posto ao lado da diversidade de relações de trabalho e de sobrevivência, de identificação étnica e de identidades políticas e de ofício, conferem grande complexidade às experiências de sociabilidade.

\section{Os endereços das associações}

O local onde fixar a sede era algo tão importante quanto as práticas e rituais entre seus sócios. Claudio Batalha, refletindo sobre a questão da localização geográfica das associações para o caso da cidade do Rio de Janeiro, aponta que a escolha do local da sede de um grupo por seus sócios não ocorria de maneira espasmódica, mas, ao contrário, seguia padrões perceptíveis. Dentre esses padrões, o mais acentuado é a busca por um local de maior visibilidade, como o centro da cidade e, uma vez no centro, a procura por lugares com maior prestígio, reforçando a ideia de que, sempre segundo Batalha, o endereço escolhido para a sede era parte da "[...] representação pública da associação". Dessa forma, essas escolhas não significavam apenas uma resposta a questões de preços de aluguéis

42 BIONDI. Classe e Nação, p. 71.

43 Fanfulla, 12/06/1910.

44 Sobre isso, ver: CACCAVELLI, Bruno. “Lazer e sociabilidade dos trabalhadores do bairro paulistano da Mooca (1900-1920)”. (Dissertação de Mestrado. Universidade Federal de São Paulo, 2015). 
ou falta de receita, mas convertiam-se sobretudo em estratégias de manutenção da existência e do fortalecimento da própria sociedade. ${ }^{45}$

Essa lógica não acidental sugerida por Batalha pode ser observada também em um recorte espacial menor dentro da cidade. Na Mooca, a maior parte das sociedades estava concentrada na rua Visconde de Parnaíba e rua da Mooca, vias que reuniam à época a maior parte do comércio e dos estabelecimentos fabris do bairro. E, entre estas, a rua da Mooca era a que apresentava, além de importantes fábricas, uma grande concentração de residências e de estabelecimentos comerciais, o que a tornava a principal via do bairro e certamente um importantíssimo centro associativo, já que, entre 1900 e 1920, quase metade das associações tiveram a sua sede instalada nesta via. ${ }^{46}$

\section{Figura 2 - Detalhe da região que compreende a rua da Mooca e a rua Visconde de Parnaíba, em mapa de 1913.47}

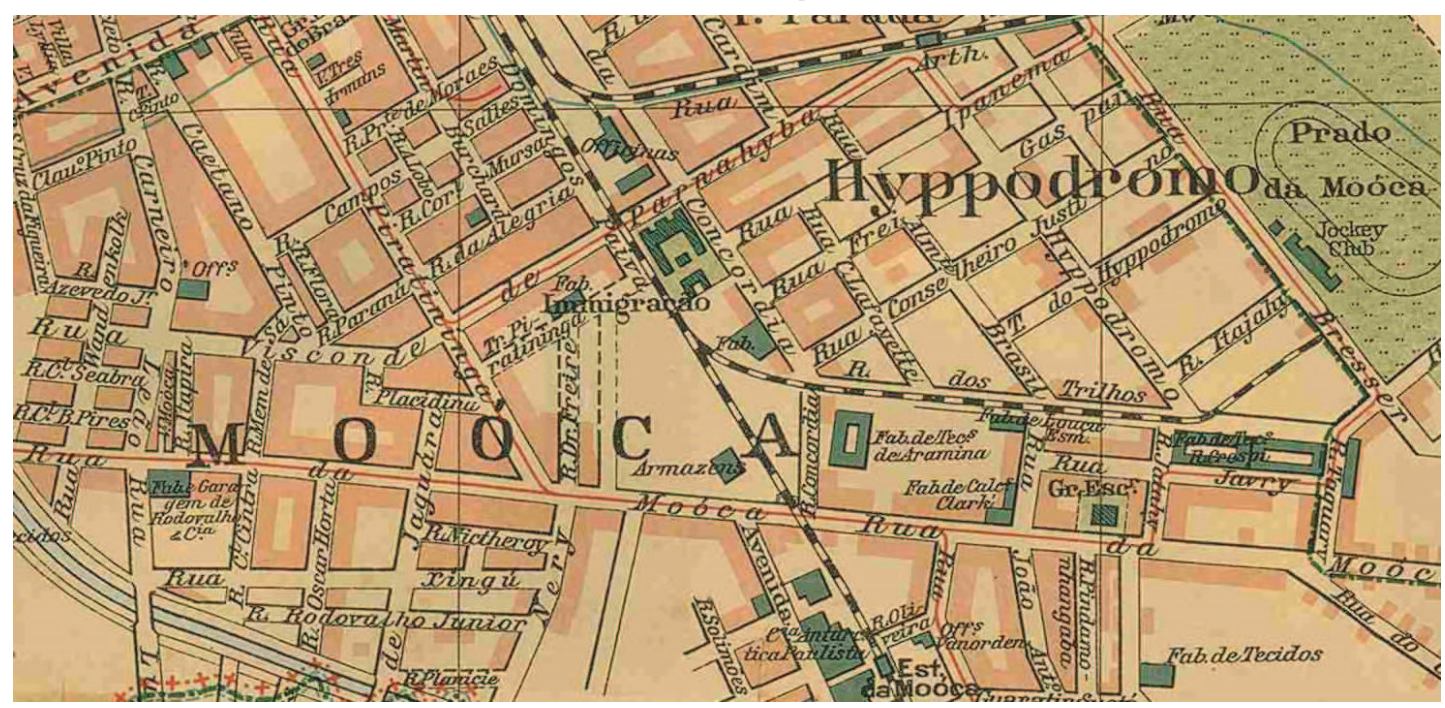

Mesmo quando já instaladas em outros locais, é possível perceber o esforço dos associados em mudar a sede para as principais vias ou para o mais próximo delas quanto fosse possível. Em 1905 a S. R. Stella d'Italia foi fundada com sede à rua Prudente de Morais, mas, dois anos mais tarde, transferiu-se para a rua Visconde de Parnaíba, n. ${ }^{\circ}$ 97. Em 1916, o Oriental Mooca F. B. C. tinha a sua sede na rua João Antônio de Oliveira, $n .^{\circ} 76$, que se localizava bem próxima da esquina com a rua da Mooca. Também a S. R. M. União da Mooca, que havia surgido em fevereiro de 1918, instalando a sua sede na rua Taquari, n. ${ }^{\circ} 97$, altura do encontro entre esta rua

45 BATALHA, Claudio. "A geografia associativa: associações operárias, protesto e espaço urbano no Rio de Janeiro da Primeira República”. In: AZEVEDO, E. et al. (Org.). Trabalhadores na cidade: cotidiano e cultura no Rio de Janeiro e em São Paulo, séculos XIX e XX. Campinas: Ed. UNICAMP, 2009, p. 260-261.

46 São elas: S. Coop. dos Cocheiros; Escola Nova, C. E. S. Francisco Ferrer; C. F. Jovens Idealistas; Guttemberg F. B. C.; Heroe das Chammas F.B.C.; União Marcial F. B. C.; S. Internacional Beneficente de São Paulo; S. O. M. S. Unione della Mooca, Banda Internacional da S. R. M. da Mooca; S. Brasil; C. R. Savoia Vincit; S. R. da Mooca; C. Infantil Flor da Mooca; S. R. D. Flor da Mooca; G. D. Amantes d'Arte; G. D. Nacional; Meridionali Uniti; Royal Recreativo da Mooca; S. D. R. E. Stella d'Italia; S. R. Giovanni Zanatello; Stella d'Italia (ligada à Meridionali); Liga dos Operários de Tecelagem da Mooca; Liga Operária da Mooca; U. G. T.

$47 \mathrm{COCOCl}$, A. M.; COSTA, Luiz F. Planta da Cidade de São Paulo. Companhia Litographica HartmannReichenbach, 1913. Disponível em: http://smdu.prefeitura.sp.gov.br/historico_demografico/. Acesso em: 1 de jun. 2015. Podemos perceber no mapa uma grande concentração de edificações que compreende quase toda a extensão da rua da Mooca e da rua Visconde de Parnaíba, como indica a faixa sombreada. Os caminhos de bondes elétricos, como observamos destacados em linhas vermelhas, já cortavam essas duas vias. 
e a rua Bresser e quase em frente ao hipódromo, mudou-se, em outubro daquele mesmo ano, para a rua Borges de Figueiredo, $n .^{\circ} 37$, bem próximo à esquina com a rua da Mooca. ${ }^{48}$

Para algumas sociedades, porém, o objetivo de se fixar mais próximas ao centro da cidade podia fazer com que abrissem mão de um endereço disputado, como a rua da Mooca, e transferissem sua sede para outras ruas do bairro onde conseguissem diminuir a distância para a região central. A U. G. T., por exemplo, mudou-se do número 292-A da rua da Mooca, onde esteve pelo menos entre dezembro de 1914 e janeiro de 1916, para a rua Visconde de Parnaíba, n. ${ }^{\circ} 125,49$ local este mais próximo ao espigão central da cidade do que o endereço anterior.

Encontrar o endereço, contudo, não é tarefa simples. É preciso lançar mão de diversas fontes - além dos estatutos, as notícias de jornais e as plantas de obras -, e cruzar todas essas informações para que conheçamos onde estavam essas sociedades. Um outro problema, porém, pode se apresentar mesmo frente a uma pesquisa extensiva sobre esses locais: muitas associações deliberadamente não informavam o local de suas sedes. Ocultar o endereço podia ter uma gama de motivos. Como já se observou, a dificuldade em obter recursos financeiros para manter em funcionamento uma associação é uma possibilidade, já que, não raro, a fragilidade das sociedades em épocas de maior dificuldade ocasionava frequentes interrupções ou mesmo o desaparecimento das agremiações. Não divulgar o endereço podia ter ainda como causa as constantes mudanças de sede, sobretudo entre os anos de 1910 e 1920, período que, como vimos, foi marcado pelo surgimento de diversas associações, mas também pela intensa repressão policial..$^{\circ}$

A procura por localidades mais prestigiosas fazia ainda com que diversas sociedades ocupassem espaços já conhecidos por abrigarem anteriormente outras associações, ainda que com intenções de uso diferentes. O número 132 da rua da Mooca, onde foi instalada em 1916 a S. R. D. Fioredella Mooca, notadamente voltada a diversas atividades recreativas, abrigou entre fevereiro de 1912 e maio de 1915 o C. E. S. "Francisco Ferrer", círculo voltado ao enriquecimento cultural e à sensibilização dos trabalhadores para a necessidade de construção de sociedades de classe. ${ }^{51}$

O leque de estratégias de sobrevivência das associações incluía também o uso compartilhado de um endereço para suas sedes. O sobrado situado no número 292-A da rua da Mooca, em 1915, chegou a abrigar 4 associações ao mesmo tempo. O local servia como sede da U. G. T., e também das escolas libertárias C. F. Jovens Idealistas, Escola Nova e Associação Universidade Popular Racionalista dirigidas por Maria Antonia Soares e Florentino de Carvalho (na verdade Primitivo Raymundo Suares), estes que possivelmente eram parentes..$^{52}$ De qualquer forma, o que se torna evidente é uma solidariedade entre associações estabelecida pelas características de cunho político e pelo tipo de atividade das associações.

A solidariedade podia ser encontrada não apenas entre aquelas associações que demonstravam uma forte aproximação em seus ideais políticos. Em 1918, o Heroe das Chammas Foot-Ball Club, que tinha a sua sede no número 13 da rua da Mooca, dividia o espaço com a Liga dos Operários de Tecelagem da Mooca, ${ }^{53} \mathrm{em}$

48 Ver as edições do Fanfulla de 16/08/1907, 01/04/1916, 23/02/1918 e 01/10/1918, respectivamente.

49 Ver A Lanterna, 19/12/1914; e Fanfulla, 23/03/1916.

50 SIQUEIRA. "Entre sindicatos, clubes e botequins", p. 21-24.

51 Fanfulla, 15/11/1916; e A Lanterna, 24/02/1912 e 01/05/1915.

52 Fanfulla, 11/12/1915; e A Lanterna, 01/05/1915 e 10/07/1915.

53 O Combate, 22/08/1918. 
um período, após as greves de 1917 com o endurecimento da repressão, em que muitas ligas operárias de bairro foram fechadas, ${ }^{54}$ o que deixava a Liga da Mooca em uma situação bastante delicada. Ao mesmo tempo, o Heroe das Chammas, uma sociedade esportiva, vivia um momento de ascensão em que clubes esportivos de trabalhadores cresciam em quantidade, inclusive na Mooca. Essa ocupação compartilhada, portanto, podia ser uma forma de possibilitar e encorajar as reuniões entre seus membros, já que, como no caso da Liga da Mooca, as dificuldades de existência se impunham a cada vez mais. Assim, atrelar-se a um clube esportivo por meio do uso compartilhado do espaço da sede, e não a outros grupos sindicais, podia apresentar-se como uma tática para desviar a atenção de agentes a serviço da polícia e dos industriais. Ainda que a tática não tenha surtido o efeito desejado - a Liga da Mooca deixou de existir ainda no mesmo ano de $1918^{55}$ - ela revela um aspecto interessante das associações da Mooca, em que as estratégias de sobrevivência passavam também pelas alianças feitas com outras sociedades, às vezes bastante próximas, mas outras vezes (aparentemente) bastante distintas em suas finalidades e atividades. Mesmo que tais uniões fossem, em último caso, apenas para a utilização do mesmo espaço como sede, essas aproximações entre sociedades diferentes dão indício de uma consciência e identidade de uma classe em formação, e tornam a vida associativa do bairro mais complexa e intricada.

\section{Funcionamento e dinâmica das associações}

De maneira geral, as associações tinham um aspecto funcional semelhante para tratar de assuntos internos, realizando assembleias e decidindo quem ocuparia os cargos diretivos por meio de eleições. Normalmente, todos os sócios quites com os pagamentos podiam votar e ser votados. Os cargos eram os de presidente e seu vice, $1^{\circ}$ e $2^{\mathrm{a}}$ secretários (ou sob o termo vice-secretário), $1^{\circ}$ e $2^{\circ}$ tesoureiros, fiscais e conselheiros (estes em número que variava de 8 a 22 membros). Esta forma de direção conferia uma condução mais democrática de organizações coletivas e era fruto das experiências vistas entre associações mutualistas, largamente influenciadas pelos socialistas, que posteriormente serviram como modelo para grupos políticos os mais diversos. ${ }^{56}$

As associações ligadas ao sindicalismo revolucionário, é preciso notar, compunham de certa maneira uma exceção à forma organizacional das associações mutualistas e tinham um funcionamento mais simples e menos ritualizado, contando geralmente apenas com uma Comissão Administrativa, ${ }^{57}$ como é o caso do C. E. S. Francisco Ferrer e da União Geral dos Trabalhadores, para ficar nesses dois exemplos. Contudo, elementos característicos de um funcionamento democrático e cujos procedimentos tinham uma certa carga de ritualização podiam ser encontrados também entre essas associações, nas assembleias para decisões coletivas que ocorriam de forma periódica. O C. E. S. Francisco Ferrer realizava assembleias anualmente - e em alguns casos semestralmente - para tratar dos assuntos mais diversos, como mostra a nota que segue:

54 LOPREATO, C. S. R. O espírito da revolta: a greve geral anarquista de 1917. São Paulo: Annablume/FAPESP, 2000, p. 157

55 O Combate, 25/09/1918.

56 BIONDI. Classe e Nação, p. 86.

57 BATALHA. "Cultura associativa no Rio de Janeiro da Primeira República”, p. 100. 
Amanhã às 6 e meia da noite se reunirá na Sede Social do Círculo Francisco Ferrer, rua da Mooca n. 132, a assembleia ordinária dos sócios para discutir a seguinte ordem do dia: 1 . Leitura da ata da assembleia anterior; 2. Nomeação de uma comissão para organizar uma festa; 3. Diversos. Por último o cidadão Angelo Scala falará sobre o tema: Parlamento e os partidos subversivos. ${ }^{5}$

Voltando às associações mutualistas, o estatuto da S. O. M. S. Unione della Mooca afirmava aquele tipo de funcionamento mais democrático, garantindo que "os cargos de presidente, vice-presidente, secretário, vice-secretário, tesoureiro, vice-tesoureiro e conselheiro são obtidos mediante eleição." Apenas uma função não passava diretamente por eleição, a de porta-bandeira, que deveria guardar e zelar pela bandeira da associação, sendo a sua nomeação responsabilidade direta do presidente. ${ }^{59}$

Também no caso da Sociedade Internacional de S. M. Mooca, assegurava-se ser

[...] administrada por uma diretoria composta de dezesseis membros eleitos anualmente com os seguintes cargos: Presidente, Vice-Presidente, $1^{\circ}$ e $2^{\circ}$ Secretário, $1^{\circ}$ e $2^{\circ}$ tesoureiro, oito Conselheiros e dois Revisores.

Neste caso, além dos cargos elegíveis mais comumente encontrados no corpo diretivo de uma associação, outros cargos eram criados de acordo com o objetivo principal da sociedade para responder às demandas mais específicas.

A Sociedade Internacional de S. M. Mooca contava ainda com duas funções para as quais se contratavam pessoas que a representariam junto ao cotidiano dos associados: o cobrador, a quem competia ir às residências para receber as mensalidades e contribuições - tomando o cuidado de usar "[...] a máxima delicadeza para com os sócios; quando o sócio não pagar a primeira vez, será este obrigado a ir a segunda" -, e entregar avisos, ofícios e circulares. E o médico, também contratado, que se ligava diretamente aos fins da sociedade, principalmente o de "auxiliar com socorros médicos os sócios e a família". A ele cabia comprovar por meio de atestados a real necessidade dos sócios em receber o auxílio, verificar a condição de saúde de alguém que fizesse a proposta de filiar-se à associação e assistir aos sócios em suas residências, caso a situação não os permitisse comparecer ao seu consultório. ${ }^{60}$

As duas associações postas acima parecem se afastar em seus objetivos específicos - auxílio médico desta última, e, da primeira, "[...] manter vivo entre os sócios o sentimento pátrio e o respeito ao Brasil e prestações de auxílio material, moral e intelectual" ${ }^{61}$-, mas elas se aproximam tanto em seu objetivo geral (o mútuo socorro), quanto em seu funcionamento, cujo teor mais democrático constitui uma das mais importantes características do processo de construção de uma identidade operária, manifestado nas decisões tomadas de forma mais coletiva. ${ }^{62}$

No caso das sociedades recreativas, musicais, teatrais e esportivas, em suma, aquelas voltadas para o lazer, foi esse formato mais elaborado o mais comumente utilizado para a sua configuração. Em 31 de outubro de 1908, um sábado, o C. F.

58 Fanfulla, 25/11/1912. Outros exemplos estão nas edições de 01/06/1910, 31/03/1913 e 23/07/1913 do mesmo jornal e em A Lanterna de 16/03/1912 e 01/05/1915.

59 Estatutos da Società Operaia di Mutuo Soccorso "Unione della Mooca". Sociedade Civil n. ${ }^{\circ} 113,1903$. Apesp.

60 Estatutos daSociedade Internacional de Socorro Mútuo da Mooca, Sociedade Civil n. ${ }^{\circ} 802$, 1921. Apesp.

61 Estatuto da Società Operaia di Mutuo Soccorso "Unione della Mooca".

62 BIONDI. Classe e Nação, p. 85-86. 
Tina di Lorenzo realizou sua primeira assembleia geral na sede instalada na rua Visconde de Parnaíba, n. ${ }^{\circ}$ 18-A. Para a reunião, estavam programadas discussões, entre outros assuntos, sobre admissão de sócios e aprovação de estatutos. $\mathrm{Na}$ segunda assembleia, no início do mês seguinte, os sócios tiveram a incumbência de eleger a nova direção, composta também pelos cargos utilizados pelas S. M. S., como o de presidente e vice, $1^{\circ}$ e $2^{\circ}$ secretários, fiscais e conselheiros. Além desses cargos mais habituais, os sócios elegeram Vincenzo Morrone e Giuseppe Fuscella, respectivamente, como $1^{\circ}$ e $2^{\circ}$ mestres de salão, funções dedicadas à manutenção e organização dos espaços da sede social onde se realizariam as peças teatrais, as festas e os bailes. ${ }^{63}$

O C. R. I. Matteo R. Imbriani realizou uma assembleia geral para a escolha de sua diretoria em 5 de julho de 1909, em sua sede à rua Visconde de Parnaíba, n. ${ }^{\circ} 175$. Na ocasião votaram para escolher os ocupantes dos cargos de presidente, vice-presidente, os de secretários, conselheiros, os de revisores de contas, fiscais, caixas e, a exemplo do Tina di Lorenzo, mestres de salão. A S. R. Giovanni Zanatello, em 08 de junho de 1909, em sua sede à rua da Mooca, n. ${ }^{\circ} 134$, realizou assembléia geral para a eleição de uma nova diretoria, o que acontecia anualmente. Os sócios da Sociedade Brasil assistiram, sete anos antes, às duas horas da tarde de um domingo, após eleição, a posse da direção que tinha a mesma composição das demais. ${ }^{64}$

A S. R. Musical da Mooca, no estatuto da sua Banda Internacional, lançado em janeiro de 1920, afirmou que "[...] todo o sócio fundador, contribuintes e perpétuos, que sejam correntes com o pagamento, têm o direito de votar e serem votados", e em sua composição diretiva figuravam os cargos de presidente, vicepresidente, secretário, tesoureiro e conselheiros. Ademais, as assembleias gerais eram realizadas duas vezes ao ano, "[...] sendo a primeira no último sábado do mês de junho e a segunda no último sábado do mês de dezembro". Entretanto, se ao apontar estas práticas e cargos a sociedade parece se encaixar entre aquelas cujo funcionamento é mais democrático, há no mesmo estatuto um elemento que levanta algumas dúvidas sobre esse caráter. 0 capítulo $6^{\circ}$ afirma que "a diretoria tem o direito de eleger secretamente uma nova Diretoria anualmente". ${ }^{65}$ Dessa forma, a diretoria podia agir no sentido de moldar a própria composição diretiva e, por consequência, a social de seus quadros, da maneira como melhor lhe conviesse ao momento, e conseguir, agindo de forma obscura - se fosse esse mesmo o caso - manter à frente da sociedade as mesmas pessoas. Contudo, é preciso lembrar, o período após a greve de 1917 trouxe às associações de trabalhadores um forte agravamento da repressão por parte dos industriais paulistas e dos poderes públicos, que agiam de diversas formas, das ações violentas até a infiltração de agentes nas associações, ${ }^{66}$ o que poderia explicar a opção adotada pela Banda Internacional de eleger, naquele período, a sua diretoria de forma secreta para conseguir se manter em funcionamento.

\section{Valores, identidades}

Os estatutos das associações formadas por trabalhadores são bastante ricos em informações como objetivos, funcionamento, critérios de admissão e formas

\footnotetext{
63 Fanfulla, 31/10/1908 e 12/11/1908.

64 Fanfulla, 04/07/1909, 12/06/1910, 08/06/1909; e O Commercio de São Paulo, 16/02/1902, respectivamente.

65 Estatutos da Banda Internacional da S. R. M. da Mooca. Sociedade n. ${ }^{\circ} 732,1920$. Apesp. Grifo meu.

66 HALL. "O Movimento Operário na Cidade de São Paulo", p. 278.
} 
de atuação e de organização. A partir dessa documentação, é possível distinguir e comparar diversas associações e perceber as tentativas de construção de diversas identidades, como de ofício, étnicas e de gênero.

Se alguém quisesse se associar a um desses grupos, teria antes que enquadrarse em determinados perfis aceitos pelas associações e expressos justamente em seus estatutos. Algumas associações preferiam não admitir novos sócios sem que fossem indicados por outros membros e devidamente investigados, ou aceitariam somente aqueles que comprovassem ter o que consideravam uma boa conduta. Outras insinuavam uma tentativa de manter em seus quadros uma composição homogênea, aceitando ou recusando filiações de acordo com o país ou região de origem do proponente, buscando reforçar uma identidade étnica ou, ao contrário, mais internacionalista.

Existem exemplos de sociedades em que claramente a etnia era um requisito central. Entre os estatutos que encontramos podemos apontar com esta característica, no entanto, apenas duas. Todavia, uma delas, a Società Italiana della Mooca, apesar de ter confirmado em seu estatuto, publicado em agosto de 1918, o desejo de "[...] consolidar os vínculos de fraternidade e solidariedade entre os italianos residentes na cidade de São Paulo e especialmente no bairro da Mooca", ${ }^{67}$ aludindo em um primeiro momento a uma vocação étnica, foi fundada por industriais e comerciantes do bairro e na prática aceitava operários brasileiros. ${ }^{68}$ Dessa forma, relacionava-se muito mais ao bairro, marcando ao mesmo tempo um forte interclassismo em suas atividades, do que com uma identidade étnica, apesar de tal identidade não ser descartada.

O outro caso é o da S. O. M. S. Unione della Mooca, que em seus estatutos afirmava ser aquela

[...] uma sociedade entre operários italianos, com sede nesta capital e denominada - Societá Operaria di mutuo Soccorso Unione Mooca cujo fim é estreitar mais os laços de fraternidade por meio de socorro mútuo e ensino.

As propostas presentes no estatuto tornavam-se visíveis na bandeira da sociedade, que "[...] é a tricolor italiana, tendo no centro representadas duas mãos que se apertam". ${ }^{69}$ Estão presentes na bandeira da Unione della Mooca tanto um símbolo étnico, nas cores italianas, quanto de classe, nas mãos unidas, indicando se tratar de uma associação que aglutinava trabalhadores que compunham as mesmas redes de imigrantes italianos, mas que também se identificavam com a classe operária, sobretudo através da ampla atuação de socialistas italianos no seio desse tipo de sociedade, fazendo com que o elemento étnico funcionasse na verdade como um fator subterrâneo de agregação. ${ }^{70}$

Existiam ainda associações em que a etnia claramente não era um critério associativo. O Grêmio Dramático 15 de Novembro tinha entre os membros da diretoria sobrenomes de origem tanto brasileira ou portuguesa quanto italiana, como

67 Estatutos da Società Italiana della Mooca, publicado no Diário Oficial do Estado de São Paulo de 18/08/1918, ed. 178, p. 4161. Grifos meus.

68 BIONDI. Classe e Nação, p. 78.

69 Estatutos da Società Operaia di Mutuo Soccorso "Unione della Mooca". Grifos meus.

70 BIONDI, Luigi. "Mãos unidas, corações divididos. As sociedades italianas de socorro mútuo em São Paulo na Primeira República: sua formação, suas lutas, suas festas”. Tempo, vol. 16, núm. 33, julio-diciembre, 2012, p. 80. Disponível em: http://www.scielo.br/pdf/tem/v18n33/a04v18n33.pdf. Acesso em: 1 de jun. 2015. 
Presidente, Arthur Silva - vice, Dario Borbolla - $1^{\circ}$ caixa, Elicer Arguelhes - $2^{\circ}$ caixa, Josino R. Gonçalves - $1^{\circ}$ secretário, Columbano Abranches diretor de salão, Angelo Graziano - $1^{\circ}$ fiscal, Domenico Daluca - $2^{\circ}$ fiscal, Mariano Gomes - auditores de contas, Eugene M. Castro, Francesco Capasso, Gugliemmo Ricci e Isidoro Lucio. ${ }^{71}$

A referência à Proclamação da República no nome da associação não deve ser interpretada como uma marca nacionalista: em primeiro lugar por causa da heterogeneidade do quadro diretivo, que indica na verdade certo internacionalismo; também porque a data adotada na nomenclatura pode surgir como uma alusão ao republicanismo, o que não é estranho se considerarmos que em 1909, por exemplo, a Associação do Livre Pensamento, de matriz libertária, comemorou a data em sua sede com uma "sessão solene", em que discursou Oreste Ristori, atacando não a República, mas seus dirigentes, sobretudo pela expulsão então recente de Edmondo Rossoni. ${ }^{72}$

Além do aspecto étnico, as associações utilizavam outros critérios na admissão de seus sócios. Para a S. O. M. S. Unione della Mooca só seriam aceitos aqueles que, além de operários e italianos, fossem maiores de 16 e menores de 60 anos e nunca tivessem sofrido “[...] condenações infamantes", e, ainda assim,

[...] a admissão se fará por meio de requerimento do candidato ou por meio de proposta de qualquer sócio, sujeito uma ou outra à deliberação secreta do conselho, que deve reunir-se para isso, desobrigado de justificar a aceitação ou recusa. ${ }^{73}$

A Sociedade Internacional de S. M. da Mooca, declarava que era "[...] composta de número ilimitado de sócios, sem distinção de nacionalidade", mas seria admitido somente aquele que

[...] for proposto por um sócio, quite com o cofre social, declarando nome, idade, nacionalidade, profissão, estado civil e residência do proposto, [...] não tenha defeitos físicos deformantes de membros que o impeçam de trabalhar e que tenham um bom comportamento. ${ }^{74}$

O "bom comportamento" frente às leis e à boa saúde daqueles que desejavam ligar-se a algum grupo estavam entre as preocupações principais das associações, e não se limitavam àquelas de mútuo socorro. A Banda Internacional afirmava que, além do "[...] bom comportamento moral”, “[...] o sócio não deve ter cometido crime de espécie alguma, e não comprometer de modo algum o bom andamento da sociedade". ${ }^{75}$ Para ser admitido como sócio do Heroe das Chammas, o proponente deveria "[...] ter bom comportamento moral e civil" e "[...] não ter sido expulso de outros Clubs por motivos desairosos". ${ }^{76}$

Ao lançar mão desses critérios, as sociedades procuravam funcionar dentro daquilo que era permitido legalmente, desvencilhando-se de atividades ilícitas e práticas ilegais, mas também evitando ter em seus quadros pessoas que pudessem ter pendências com a polícia - o que poderia acarretar em problemas para a própria associação.

71 Fanfulla, 09/01/1915.

72 A Lanterna, 20/11/1909.

73 Estatutos da Società Operaia di Mutuo Soccorso "Unione della Mooca".

74 Estatutos da Sociedade Internacional de Socorro Mútuo da Mooca.

75 Estatutos da Banda Internacional.....

76 Estatutos do Heroe das Chammas Foot Ball Club. Sociedade n. ${ }^{\circ} 826,1921$. Apesp. 
A exigência de se estar em gozo de boa saúde pode ser encarada tanto como um resguardo das associações - sobretudo das mutualistas que em geral garantiam o socorro em caso de doenças - quanto um critério decorrente da experiência vivida durante a Gripe Espanhola, que assolou principalmente os bairros chamados operários da cidade de São Paulo em 1918.

Critérios como esses, como ter "bom comportamento", "emprego honesto", ou o de nunca ter sido implicado em crimes de nenhuma espécie, como observa Uassyr de Siqueira, eram o reflexo da busca de construção de um perfil associativo ajustado por valores tais como honestidade e valorização do trabalho, e eram inerentes às associações autogeridas por trabalhadores, distanciando-se dos requisitos normalmente empregados por clubes ligados às camadas abastadas da sociedade, cujo teor indicava diferenciação a partir do destaque econômico ou social de que gozava um indivíduo na sociedade paulistana. ${ }^{77}$

Esses mesmos critérios associativos davam mostra da existência de alguns códigos próprios dos trabalhadores. Para essas associações, a disciplina era extremamente necessária para a sua existência e algo indispensável às suas ações, mesmo as mais comuns, tais como gerir o caixa social, organizar e realizar reuniões, resolver situações de conflito interno, e exigia, para lembrar uma vez mais de Thompson, "[...] um autocontrole tão grande quanto a nova disciplina do trabalho". ${ }^{78}$ Não por acaso, a imposição de multas e penalidades dispostas nos estatutos eram bastante severas. A Banda Internacional previa a demissão dos sócios "[...] que procurarem desmoralizar esta sociedade", e dos que "[...] faltarem três vezes consecutivas às reuniões sem motivo justificado". Quanto à previsão da punição pelo atraso da mensalidade, principal fonte de recursos da associação, o termo demissão - que poderia ser em alguns casos ser revertido em readmissão após deliberações do conselho - foi substituído por outro mais permanente: "eliminação". ${ }^{99}$

Para o Heroe das Chammas, o atraso no pagamento das contribuições em mais de dois meses acarretaria em suspensão de todos os direitos associativos do devedor, até que as mensalidades fossem quitadas. A eliminação, contudo, estava prevista para a maior parte das faltas: o atraso das mensalidades em mais de três meses, a difamação do clube, os que fossem "[...] condenados por crimes infamantes", os que fraudassem os cofres sociais, os que não prestassem contas de seus atos em nome da associação. ${ }^{80}$

Todos estes códigos, necessários à manutenção das sociedades constituídas entre os trabalhadores, são sinais de aquisição de autodisciplina e de consciência dos trabalhadores frente às adversidades e quanto à sua organização. Enfim, elementos indicadores da classe operária em formação. ${ }^{81}$

\section{Conclusão}

A grande quantidade de associações de trabalhadores fundadas na cidade de São Paulo, sobretudo nas duas primeiras décadas dos anos $1900,{ }^{82}$ conformam, em conjunto, para emprestar uma última vez as palavras de Thompson, "[...] a aquisição

77 SIQUEIRA. "Entre sindicatos, clubes e botequins".

78 THOMPSON, E. P. A Formação da Classe Operária Inglesa. v. 2. Rio de Janeiro: Paz e Terra, 1987, p. 311.

79 Estatutos da Banda Internacional....

80 Estatutos do Heroe das Chammas Foot Ball Club.

81 THOMPSON. A Formação da Classe Operária Inglesa, v. 2, p. 312.

82 Ver BIONDI. Classe e Nação; SIQUEIRA. "Clubes e Sociedades dos Trabalhadores do Bom Retiro". 
de autodisciplina e a difusão de experiências, num grau impressionante". ${ }^{83}$ Ao nos debruçarmos sobre as associações formadas por trabalhadores do bairro da Mooca, este que apresentava uma grande heterogeneidade cultural e identitária, foi possível ver um grande número de associações dos mais variados tipos em que uma multiplicidade de experiências e de vínculos identitários eram possíveis, além de existirem diversas interconexões associativas, revelando uma grande circulação de ideias e experiências. Percebe-se, com isso, uma grande complexidade nas experiências de sociabilidade dos trabalhadores da Mooca no período proposto. Mesmo tendo em conta fatores adversos, tais como o interclassismo, as dificuldades de manutenção e a repressão, foi possível entrever nas escolhas e práticas dessas associações elementos tais como a solidariedade, a condução democrática, o internacionalismo, valores coletivistas que norteavam códigos inerentes aos trabalhadores, denotando, finalmente, uma consciência de classe.

Recebido em 08/06/2015

Aprovado em 05/11/2015

83 THOMPSON. A Formação da Classe Operária Inglesa, v. 2, p. 313. 